\title{
CLINICAL AND RADIOLOGICAL EVALUATION OF ELONGATED STYLOID PROCESS IN PATIENTS WITH TEMPOROMANDIBULAR JOINT DISORDER
}

\begin{abstract}
Objectives: Clinical findings of elongated styloid process (SP) can easily be confused with clinical symptoms associated with temporomandibular joint disorders (TMD). This study aims to investigate the presence of elongated SP in patients with TMD.

Materials and Methods: This retrospective study was performed on the digital panoramic radiographs of 300 patients between 14-68 years of age, where the study group consisted of 150 (300 SP) patients diagnosed with TMD and the control group consisted of 150 (300 SP) individuals without TMD. 224 of the patients were female and 76 were male. SP measurement was performed by a physician with radiography experience. The measurement values higher than 30 mm were accepted as elongated SP.
\end{abstract}

Results: There was a significant difference between the TMD group and the control group in terms of SP length $(\mathrm{p}<0.05)$. While $62 \%$ of the patients with TMD had elongated SP, this rate was $38 \%$ in the control group.

Conclusions: Elongated SP rate was higher in patients with TMD. Since TMD and Eagle syndrome have similar clinical findings, physicians should consider the differential diagnosis of patients with TMD compared to Eagle's syndrome.

Key words: Temporomandibular joint disorder, eagle syndrome, styloid process
(D) Günay Yapıcı Yavuz ${ }^{1}$

(D)*Aydın Keskinrüzgar ${ }^{1}$

ORCID IDs of the authors: G.Y.Y.0000-0002-1093-6297

A.K.0000-0001-5735-6890 ${ }^{1}$ Department of Oral and Maxillofacial Surgery
Faculty of Dentistry, Adiyaman University, Adiyaman, Turkey

$\begin{array}{ll}\text { Received } & : 18.12 .2018 \\ \text { Accepted } & : 16.01 .2019\end{array}$

How to Cite: Yavuz GY, Keskinrüzgar A. Clinical and Radiological Evaluation of Elongated Styloid Process in Patients with Temporomandibular Joint Disorder Cumhuriyet Dent J 2019;22:1:37-41. 


\section{INTRODUCTION}

The number of patients with temporomandibular joint disorder (TMD) and orofacial pain has been increasing. Approximately $40 \%$ to $75 \%$ of the population exhibit TMD symptoms. ${ }^{1,2}$ TMD is a term used for diseases that affect a large area including the temporomandibular joint (TMJ) and the chewing muscles. In the preauricular region, symptoms such as pain on palpation, limited jaw movements, joint noises, persistent pain, headache, ear pain, tinnitus, and dizziness are observed accompanying TMD. These symptoms can sometimes be confused with the symptoms of other diseases in this region..$^{1,3,4}$

Eagle syndrome is not widely known among dentists. The styloid process (SP) in the temporal bone is located near the TMJ on the inferior side of the skull. Styloid process is a $20-30 \mathrm{~mm}$ long cylindrical bone, which is located in the caudalanterior and slightly medial direction, near important cervical veins and nerves. When the SP is longer than $30 \mathrm{~mm}$, it is defined as an elongated SP. ${ }^{4,5}$ Symptomatology, clinical and radiological diagnosis and treatment of elongated SP were first described by Eagle in $1937 .{ }^{6}$ The SP is also known as styloid syndrome, stylohyoid syndrome, elongated styloid protrusion, and styloid protrusion neuralgia. Eagle syndrome is a term used for the symptomatic extension of the SP or the mineralization of the stylohyoid or stylomandibular ligament. ${ }^{7,8}$ Elongated SP may be asymptomatic, however, when symptoms occur (Eagle syndrome), foreign body sensation in the throat, dysphagia, ear pain, headache, eye pain, pain in the TMJ area, and tooth pain may be present. ${ }^{5,9,10}$ Many of these findings may also be associated with TMD. Some findings can be found in both TMD and Eagle syndrome. ${ }^{9,10}$ In the diagnosis of elongated SP, pain occurring during palpation of the tonsillar fossa and SP felt by hand are used and this diagnosis can be supported by digital panoramic radiography and computed tomography. ${ }^{11}$ The aim of this study was to determine the SP length from the digital panoramic images in TMD patients.

\section{MATERIALS AND METHODS}

This study was approved by the Adiyaman University Non-Interventional Clinical Research Ethics Committee (Protocol no: 2018 / 4-27). The study protocol consisted of two groups of patients who applied to Adiyaman University, Faculty of Dentistry, Oral and Maxillofacial Surgery Clinic; one group consisted of patients diagnosed with TMD (TMD group) while the other group included individuals who did not have any complaints in the TMJ region and the surrounding area (control group). For the diagnosis of TMD, RDC/TMD criteria (research diagnostic criteria for TMDs) were taken into account. ${ }^{12}$ Also, pain and tenderness in the TMJ region and in the masticatory muscles lasting at least 3 months, a psychopathological disease and the absence of previous TMJ surgery were included in the selection criteria. $^{12}$ In this retrospective study, digital panoramic radiographs of 150 patients (300 SP) in the TMD group and 150 individuals (300 $\mathrm{SP})$ in the control group were analyzed and SP was evaluated bilaterally. Clinical and radiological examinations were performed by an experienced oral surgeon. The radiograph results were randomly numbered by another investigator without separation into groups, ensuring the reliability of the study result. The digital panoramic radiographs that were utilized in this study were taken with a panoramic x-ray device (Planmeca, Promax, Helsinki, Finland) at the Faculty of Dentistry of Adiyaman University. The length of SP was measured by an experienced oral surgeon with the digital bar of Romexis 2.9.2 program which was used in the Faculty of Dentistry during radiographic evaluations. Digital measurement calibration was performed before each measurement. The length between SP endpoint and tympanic bone was measured to determine the SP length, as described by İlgüy et al. ${ }^{13}$ A SP length of $20-30 \mathrm{~mm}$ was defined as normal length, whereas longer SP was called elongated SP (Figure 1). 


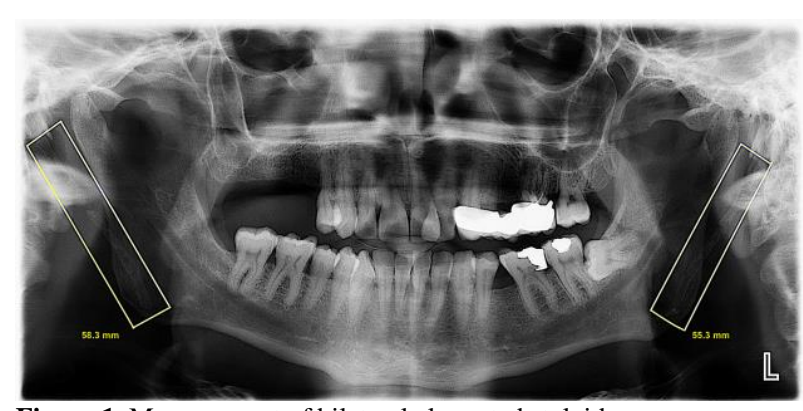

Figure 1. Measurement of bilateral elongated styloid process.

\section{Statistical Analysis}

The data obtained in this study were analyzed with IBM SPSS Statistics Version 22 package program. When analyzing the variables with a normal distribution, Shapiro Wilks was used because of the number of units. When interpreting the results, 0.05 was used as the level of significance. In the case of $p<0.05$, the variables were assumed not to have a normal distribution, while for $p>0.05$ it was stated that the variables exhibit a normal distribution. When examining the differences between the groups, the Mann Whitney U Test was used because the variables did not have a normal distribution. The chi-square analysis was applied to examine the relationships between the groups of the nominal variables. When interpreting the results, 0.05 was used as the level of significance and it was stated that there was a significant relationship in the case of $p<0.05$ and no significant relationship in the case of $p>0.05$.

\section{RESULTS}

The study consisted of 150 patients with bilateral TMD (300 SP) and 150 control patients (300 SP). Of these patients, 224 were female and 76 were male, aged between 14-68 years. The TMD group consisted of 115 females and 35 males, and the mean age was $29.98 \pm 11.8$ years, while the control group consisted of 109 women and 41 men, with a mean age of $30 \pm 7.8$ years. There was no statistically significant difference in terms of gender between the groups ( $p>0.05)$. There was also no statistically significant difference with respect to age between the groups ( $>0.05)$. Age and gender distributions between the groups were homogeneous (Table 1).
Table 1. Distribution of the sex and age between groups.

\begin{tabular}{|c|c|c|c|c|c|c|}
\hline \multicolumn{7}{|c|}{ Groups } \\
\hline & & \multicolumn{2}{|c|}{ TMD } & \multicolumn{2}{|c|}{ Control } & $\begin{array}{l}\text { Chi Square } \\
\text { Test p value }\end{array}$ \\
\hline Sex & $\begin{array}{l}\text { Female } \\
\text { Male }\end{array}$ & $\begin{array}{c}\mathbf{n} \\
115 \\
35 \\
\end{array}$ & $\begin{array}{c}\% \\
76.7 \\
23.3 \\
\end{array}$ & $\begin{array}{c}\mathbf{n} \\
109 \\
41 \\
\end{array}$ & $\begin{array}{c}\% \\
72.7 \\
27.3 \\
\end{array}$ & 0.426 \\
\hline \multicolumn{7}{|c|}{ Groups } \\
\hline Age & & $\begin{array}{r}\text { T } \\
\mathbf{M e} \\
29.9\end{array}$ & $\begin{array}{l}\mathbf{D} \\
\pm \mathbf{S d} \\
11.1\end{array}$ & $\begin{array}{r}\text { Co } \\
\mathbf{M e} \\
30\end{array}$ & & $\begin{array}{c}\text { Mann } \\
\text { Whitney U } \\
\text { Test p value } \\
0.350\end{array}$ \\
\hline
\end{tabular}

TMD: Temporomandibular Joint Disorders Sd: Standard deviation

There was a statistically significant difference in SP length between the groups $(p<0.05)$. The mean length of SP in the TMD group was $32.65 \pm$ $6.35 \mathrm{~mm}$ (Min: 17.6; Max: 62.5), while the mean SP was $29.36 \pm 3.92 \mathrm{~mm}$ in the control group (Min: 20.4; Max: 41.4) (Table 2).

Table 2. Comparison of groups in terms of bilateral styloid process.

\begin{tabular}{lcccccc}
\hline & & & & & & \multicolumn{1}{c}{$\begin{array}{c}\text { Mann } \\
\text { Whitney } \\
\text { U Testi } \\
\text { p value }\end{array}$} \\
\hline TMD & 300 & 32.65 & 17.6 & 62.5 & 6.35 & p \\
Control & 300 & 29.36 & 20.4 & 41.4 & 3.92 & \\
\hline
\end{tabular}

TMD: Temporomandibular Joint Disorders, Sd: Standard deviation.

In addition, 62\% of patients with TMD had elongated SP and $38 \%$ had normal SP. In the control group, $63 \%$ of the patients had normal SP lengths and $27 \%$ of them had elongated SP (Table $3)$.

Table 3. Elongated styloid process rate in the TMD and control groups

\begin{tabular}{ccc}
\hline $\begin{array}{c}\text { Styloid process } \\
\text { lengths }\end{array}$ & $\begin{array}{c}\text { Bilateral TMD } \\
(\mathbf{n}=\mathbf{3 0 0})\end{array}$ & $\begin{array}{c}\text { Bilateral Control } \\
(\mathbf{n = 3 0 0})\end{array}$ \\
\hline$>\mathbf{3 0} \mathbf{~ m m}$ & $186(\% 62)$ & $111(\% 37)$ \\
$<\mathbf{3 0} \mathbf{~ m m} . \mathbf{3 0 m m}$ & $114(\% 38)$ & $189(\% 63)$ \\
\hline
\end{tabular}

TMD: Temporomandibular Joint Disorders

\section{DISCUSSION}

Elongated SP is a common condition and its prevalence is between $1.4 \%$ and $83.6 \% .^{14-16}$ According to the literature, most elongated SPs are not associated with any clinical symptoms. A low percentage of patients with orofacial and neck pain (approximately 5\%) have been reported to have elongated SP. ${ }^{17}$ The etiology of elongated SP is still unknown. It has been reported that there may be various reasons such as congenital elongation, stylohyoid ligament ossification and 
osseous tissue growth on the stylohyoid ligament. ${ }^{18}$ Eagle syndrome, which occurs when elongated SP is symptomatic, is difficult to diagnose because its symptoms resemble the symptoms of pathologies originating from the oral and maxillofacial region. It can be easily confused with a toothache and TMD, which may result in misdiagnosis and unnecessary procedures. Therefore, dentists should be aware of the differential diagnosis of these diseases. ${ }^{19}$

Both detailed patient anamnesis and radiological analysis should be done in elongated SP patients. Therefore, the radiological analysis is very important in these studies. Andrade et al. compared the results of digital lateral cephalometric radiography and digital panoramic radiography to determine the SP length and found that the results were close to each other which suggested the digital panoramic radiographs to be a reliable method in the measurement of SP length. ${ }^{1}$ Similarly, digital panoramic radiography images were used for SP measurements in the present study.

There is no consensus regarding the relationship between SP length and gender; although some studies ${ }^{20,21}$ report that SP length and gender are associated, others ${ }^{4,7,10,13}$ report that there is no relationship between SP length and gender. In our study, there was no statistically significant association between the SP length and gender.

There is no consensus regarding the relationship between SP length and age. While several studies ${ }^{20,21}$ have reported that there is a relationship between SP length and age, others ${ }^{7,20-}$ ${ }^{23}$ have reported that there is none. In our study, we found no statistically significant relationship between the SP length and age.

There are very few studies on the prevalence of elongated SP in patients with TMD. Zaki et al. ${ }^{9}$ reported that $27 \%$ of the patients with TMD had elongated SP in a study on 100 patients. De Andrade et al. ${ }^{1}$ investigated SP length and clinical symptoms in a study on 50 patients with TMD and found that $76 \%$ of patients had elongated SP. They reported that elongated SP prevalence was high in patients with TMD, but there was no correlation between symptoms such as a headache, orofacial pain, tinnitus and vertigo, and the SP length. Krohn et al. ${ }^{4}$ found that the mean SP was $40.8 \mathrm{~mm}$ in patients with TMD and the prevalence of elongated SP was high. In contrast to these studies, Sancio-Golçalves et al. ${ }^{10}$ reported that there was no statistically significant association between TMD and SP length.

In our study, the mean SP length was 32.65 $\mathrm{mm}$ and $29.36 \mathrm{~mm}$ in the TMD group and the control group, respectively. While $62 \%$ of the patients with TMD had elongated SP, 38\% had normal SP. These data suggest that the prevalence of elongated SP is high in patients with TMD. The present study analyzed the highest number of SPs in the literature. In addition, this study is the first to examine the relationship between TMD and elongated SP in the Turkish population.

\section{CONCLUSIONS}

Based on the findings of our study, we conclude that:

- Panoramic radiographs are sufficient for determining SP length.

- The prevalence of elongated SP in patients with TMD is high. Dentists should examine patients presenting with TMD in clinically and radiologically more detail and should consider Eagle's syndrome for differential diagnosis in the presence of elongated SP.

\section{ACKNOWLEDGEMENTS}

None

\section{CONFLICTS OF INTEREST}

None

Temporomandibular Eklem Düzensizliği Bulunan

Hastalarda Styloid process Uzamasının Klinik ve Radyolojik Olarak Değerlendirilmesi

$\ddot{O} Z$

Amaç: Uzamış styloid process klinik bulgular, TMD ile ilişkili klinik semptomlar ile kolaylıkla karışabilmektedir. Bu çalışma TMD bulunan hastalarda uzamış SP varlı̆̆ının araştırılmasını amaçlamaktadır. Gereç ve Yöntemler: Bu çalışma, TMD tanısı konulan 150 (300 SP) hasta ve kontrol 
grubu olarak da 150 (300 SP) bireyin dijital panoramik radyografileri retrospektif olarak incelenmesi ile yapuld. Hastaların 224'ü kadın ve 76'si erkek olup, 14-68 yaş aralığındadır. SP ölçümü radyografi üzerinde tecrübeli bir hekim tarafindan yapıld. $30 \mathrm{~mm}$ 'den yüksek olan ölçüm değeri uzamış SP olarak kabul edildi. Bulgular: Gruplar karşılaştırıldığında, TMD bulunan grup ile kontrol grubu arasında SP uzunluğu bakımından anlamlı farklılık bulunmuştur $(p<0,05)$. TMD bulunan hastaların \%62 uzamış SP mevcut iken, kontrol grubunda bu oran \%38'dir. Sonuçlar: TMD bulunan hastalarda uzamış SP oranı daha fazla görülmektedir. TMD ve Eagle sendromu benzer klinik bulgulara sahiptir. Bu nedenle, hekimler TMD bulunan hastaları muayene ederken Eagle sendromu bakımından da ayırıcı tanısını göz önünde bulundurmalılardır. Anahtar Kelimeler: Temporomandibular eklem hastalı̆̆l, eagle sendromu, styloid proçes.

\section{REFERENCES}

1. Andrade KM, Rodrigues CA, Watanabe PA, Mazzetto MO. Styloid Process Elongation and Calcification in Subjects with TMD: Clinical and Radiographic Aspects. Braz Dent J 2012;23: 443-450.

2. De Leeuw R. Orofacial pain: guidelines for assessment, diagnosis and management. The American Academy of Orofacial Pain. Chicago: Quintessence Int 2008;4: 2-5.

3. Tuz HH, Onder EM, Kisnisci RS. Prevalence of otologic complaints in patients with temporomandibular disorder. Am J Orthod Dentofacial Orthop 2003;123: 620-623.

4. Krohn S, Brockmeyer P, Kubein-Meesenburg D, Kirschneck C, Buergers R. Elongated styloid process in patients with temporomandibular disorders. Annals of Anatomy 2018;217: 118-124.

5. Palesy P, Murray GM, De Boever J, Klineberg I. The involvement of thestyloid process in head and neck pain -a preliminary study. J. Oral Rehabil 2000;27: 275-287.

6. Eagle W. W. Symptomathic elongated styloid process. Report of two cases of Styloid process. Arch Otolaryngol 1937;25: 584-587.

7. Nalçacı R. Mısırlıŏlu M. Yaşlı bireylerde stiloid proçesin radyolojik olarak değerlendirilmesi. Atatürk Üniv Diş Hek Fak Derg 2006;16: 1-6.

8. Schroeder WA. Traumatic Eagle's syndrome. Otolaryngol Head Neck Surg 1991;104: 371-374.

9. Zaki HS, Greco CM, Rudy TE, Kubinski JA. Elongated styloid process in a temporomandibular disorder sample: prevalence and outcome. J Prosthet Dent 1996;75: 399-405.

10. Sancio-Gonçalves FC, Abreu MHNG, Soares JMN, Amaral SA, Porfirio FMB, Naves MD, Abdo EN.
Stylohyoid Complex Ossification in Temporomandibular Disorders: A Case-control Study. J Prosthet Dent 2013;109: 79-82.

11. Tunçdemir AR, Büyükerkmen EB, Çelebi $H, A k ı n$ C. Bruksizmi Olan Hastalarda Styloid Process Uzunluğunun Değerlendirilmesi. Atatürk Üniv. Diş Hek. Fak. Derg. 2017;27: 39-42.

12. Dworkin SF, LeResche L. Research diagnostic criteria for temporomandibular disorders: review, criteria, examinations and specifications, critique. J Craniomandib Disord. 1992;6: 301-355.

13. İlgüy M, İlgüy D, Güler N, Bayırlı G. Incidence of the type and 2. calcification patterns in patients with elongated styloid process. J Int Med Res 2005;33: 96102.

14. Gracco A, De Stefani A, Bruno G, Balasso P, Alessandri- Bonetti G, Stellini E. Elongated styloid process evaluation on digital panoramic radiograph in a North Italian population. J Clin Exp Dent 2017;9: 400404.

15. Shaik MA, Naheeda, Kaleem SM, Wahab A, Hameed S. Prevalence of elongated styloid process in Saudi popula-tion of Aseer region. Eur J Dent 2013;7: 449.

16. Öztaş B, Orhan K. Investigation of the incidence of stylohyoid ligament calcifications with panoramic radiographs. J Invest Clin Dent 2012;3: 30-35.

17. Prasad KC, Kamath MP, Reddy KJ, Raju K, Agarwal S. Elongated styloid process (Eagle's syndrome): a clinical study. J Oral Maxillofac Surg 2002;60: 171-175.

18. Kamal A, Nazir R, Usman M, Salam B, Sana F. Eagle syndrome; radiological evaluation anad management. J Pak Med Assoc 2014;64: 1315-1317.

19. Ferreira PC, Mendanha M, Frada T, Carvalho J, Silva A, Amarante J. Eagle Syndrome. J Craniofac Surg 2014;25: 84-86.

20. Okabe S, Morimoto Y, Ansai T, Yamada K, Tanaka T, Awano S, Kito S, Takata Y, Takehara T, Ohba T. Clinical significance and variation of the advanced calcified stylohyoid complex detected by panoramic radiographs among 80-year-old subjects. Dentomaxillofacial Radiology 2006;35: 191-199.

21. Rizzatti-Barbosa CM, Ribeiro MC, Silva-Concilio LR, swaldo Di Hipolito O, Ambrosano GM. Is an elongated stylohyoid process prevalent in the elderly? A radiographic study in a Brazilian population. Gerodontology 2005;22;112-115.

22. Jung T, Tschermitschek H, Hippen H, Schneider B, Borchers L. Elongated styloid process: when is it really elongated? Dentomaxillofac Radiol 2004;33: 119-124. 23. Kursoglu P, Unalan F, Erdem T. Radiological evaluation of the styloid process in young adults resident in Turkey's Yeditepe University faculty of dentistry. Oral Surg Oral Med Oral Pathol Oral Radiol Endod 2005;100: 491-494. 